\title{
The degree of financial liberalization and aggregated stock-return volatility in emerging markets
}

\author{
Mehmet Umutlu ${ }^{\mathrm{a}, *}$, Levent Akdeniz ${ }^{\mathrm{b}}$, Aslihan Altay-Salih ${ }^{\mathrm{b}}$ \\ a Faculty of Economics and Administrative Sciences, Çankaya University, 06530 Ankara, Turkey \\ ${ }^{\mathrm{b}}$ Faculty of Business Administration, Bilkent University, 06800 Ankara, Turkey
}

\section{A R T I C L E I N F O}

\section{Article history:}

Received 15 July 2008

Accepted 17 August 2009

Available online 19 August 2009

\section{JEL classification:}

F36

G15

\section{Keywords:}

Return volatility

Financial liberalization

Market integration

Volatility decomposition

Emerging markets

\begin{abstract}
A B S T R A C T
In this study, we address whether the degree of financial liberalization affects the aggregated total volatility of stock returns by considering the time-varying nature of financial liberalization. We also explore channels through which the degree of financial liberalization impacts aggregated total volatility. We document a negative relation to the degree of financial liberalization after controlling for size, liquidity, country, and crisis effects, especially for small and medium-sized markets. Moreover, the degree of financial liberalization transmits its negative impact on aggregated total volatility through aggregated idiosyncratic and local volatilities. Overall, our results provide evidence in favor of the view that the broadening of the investor base due to the increasing degree of financial liberalization causes a reduction in the total volatility of stock returns.
\end{abstract}

(c) 2009 Elsevier B.V. All rights reserved.

\section{Introduction}

Many emerging markets liberalized their capital markets in the last few decades. ${ }^{1}$ With the removal of restrictions on cross-border transactions, investors participate in emerging markets to take advantage of high returns in these markets and to reduce the risk of their portfolio by international diversification. Financial liberalization provides some advantages for emerging markets, too. It fosters the stock market development (De La Torre et al., 2007), lowers the cost of capital (Bekaert and Harvey, 2000; Chari and Henry, 2004), which, in turn, leads to investment booms (Henry, 2000) and thus spurs economic growth (Bekaert et al., 2005; Moshirian, 2008). On the other hand, some researchers share the concern that financial liberalization causes excess volatility in emerging markets (Bae et al., 2004; Li et al., 2004; Stiglitz, 2004). However, there is no consensus about this view in the literature. For example, De Santis and Imrohoroglu (1997), Hargis (2002) and Kim and Singal (2000) find either a reducing impact or no impact of financial liberalization on volatility.

Uncovering the ambiguity in the relationship between financial liberalization and volatility has policy and asset allocation implica-

\footnotetext{
* Corresponding author. Tel.: +90 312284 4500x341; fax: +90 3122864873.

E-mail addresses: mehmetumutlu@cankaya.edu.tr (M. Umutlu), akdeniz@bilkent.edu.tr (L. Akdeniz), asalih@bilkent.edu.tr (A. Altay-Salih).

${ }^{1}$ See (Moshirian, 2007) for a historical review on global integration.
}

tions. For instance, any possible adverse volatility effects may lead governments to employ restrictive regulatory shifts over foreign equity investments, especially in emerging markets, diminishing the ability of firms to raise capital for profitable projects and thus resulting in poor economic growth. It is also important for financial managers to understand the effects of financial liberalization on the volatility of stock returns since high stock-return volatility can lead to an increase in firms' cost of capital. Finally, portfolio managers are interested in this particular research question, as they might need to rebalance their portfolios to properly reflect the risk preferences of their investors due to potential changes in the risk profiles of their holdings stemming from changes in the degree of financial liberalization.

Most of the previous works assume that financial liberalization occurs at a single point in time and treats it as a one-time event. These studies mainly analyze time-series characteristics of the volatility of local market indexes in the event window around the liberalization date and use alternative event dates for financial liberalization. ${ }^{2}$ Different liberalization dates may lead different inferences in such studies, which may be one reason why mixed

\footnotetext{
${ }^{2}$ For instance, regulatory reform date (Kim and Singal, 2000; De Santis and Imrohoroglu, 1997; Chari and Henry, 2004), announcement of the first American Depository Receipt or the first country fund (Foerster and Karolyi, 1999; Umutlu et al., 2007) are some of the alternative event dates used in the literature.
} 
results are obtained in the literature. However, some studies (Bekaert and Harvey, 2002; Bae et al., 2004; Edison and Warnock, 2003) show that the implementation and speed of financial liberalization varies, depending on the conditions of local markets. Researchers now agree that for many emerging markets, financial liberalization is a process rather than an event and that its intensity and speed changes over time. Another possible problem in the previous literature is the analysis of the return variance of a market portfolio to make inferences about average stock-return variances. This practice may cause erroneous results because a change in the variance of a portfolio may be due to changes in the covariances of the stocks forming the portfolio, without an accompanying change in their variances.

In this study, we address whether the degree of financial liberalization affects the aggregated total volatility of stock returns by considering the time-varying nature of financial liberalization. The degree of financial liberalization represents the extent of the removal of restrictions on cross-border transactions through time. By using several continuous measures for the degree of financial liberalization, we not only properly specify the gradual nature of financial liberalization but also eliminate the imprecision problem in dating the liberalization. Our next objective in this study is to determine the channels through which the degree of financial liberalization transmits its impact onto aggregated total volatility. For this purpose, we extend the volatility decomposition of Campbell et al. (2001) in a modified market model framework. Campbell et al. (2001) decompose the aggregated return volatility of stocks by using a methodology that does not require the estimation of covariance or stock beta terms. In our extended model, we model the returns of individual stocks to be driven both by local and global portfolio returns, and thus, we consider the partially segmented/integrated nature of many emerging markets. ${ }^{3}$ The appealing feature of our extended model is that it accounts for the conditional effect of one factor, given the other. By value weighting the return volatility of stocks in a country, we decompose aggregated total volatility into local, global and idiosyncratic volatility. After this volatility decomposition, we are able to examine through which components of aggregated total volatility is affected. Interestingly, no other study in the literature investigates the mechanisms through which the degree of financial liberalization transmits its impact on aggregated total volatility. Moreover, unlike previous studies that examine the return volatility of a market portfolio, we analyze the aggregated total volatility of stocks. Our aggregated volatility measure is independent of the co-variation in stock returns and therefore, is a pure measure of the average stock-return volatility in a country.

We find that the degree of financial liberalization has a negative impact on aggregated total volatility, even after controlling for size, liquidity, country and crisis effects, especially for small and medium-sized markets. We find similar results with binary modeling of financial liberalization and for different time periods. Furthermore, we show that the degree of financial liberalization transmits its reducing impact on aggregated total volatility through aggregated idiosyncratic and local volatilities. This finding is robust to the alternative order of orthogonalization of returns in the volatility decomposition process and to the alternative model-independent definition of idiosyncratic volatility. The documented negative relationship between total volatility and the degree of financial liberalization is consistent with earlier studies suggesting a decrease in volatility due to the investor-base broadening phenomena. A broadened investor base, stemming from the entry of foreign investors during the financial liberalization process, can

\footnotetext{
3 Errunza and Losq (1985), Chari and Henry (2004), De Jong and De Roon (2005) and Panchenko and $\mathrm{Wu}$ (2009) are examples of studies that follow the partial segmentation/partial integration paradigm.
}

cause a decrease in total volatility because of an improvement in the market-wide accuracy of public information.

The rest of the article is organized as follows: Section 2 discusses the theoretical motives for a possible relationship between the degree of financial liberalization and volatility. This section also introduces the details of the construction and decomposition of aggregated total volatility. Section 3 describes the data and the estimation methodology of aggregated total volatility and its components. Section 4 analyzes the relationship between aggregated total volatility and the degree of financial liberalization; Section 5 extends the analysis to include the volatility components and the final section concludes the study.

\section{Aggregated total volatility, its components and the degree of financial liberalization}

\subsection{How can the extent of financial liberalization affect total volatility and its components?}

Several theoretical studies attempt to explain how financial liberalization may affect the level of volatility. Stiglitz (2004) states that financial liberalization leads to instability in the economy by increasing the consumption and output volatility, which are mainly caused by the pro-cyclical nature of foreign capital flows, in the presence of market imperfections such as information asymmetry and incomplete markets. On the other hand, by extending Merton (1987)'s investor-base broadening hypothesis, Wang (2007) shows that increasing number of foreign investors as a result of financial liberalization causes a decrease in total return volatility of stocks in a market where each investor only knows a subset of the available securities. ${ }^{4}$ Every added investor helps complete the information in a market where the existing investors have only partial information on a subset of available stocks and where these subsets differ across investors. As a result, an increased investor base increases the accuracy of market-wide information and cause a reduction in total volatility. In a similar vein, Kwan and Reyes (1997) analytically show a reduction in volatility with the broadening of the investor base in a market where investors have heterogeneous information about stock prices. Domowitz et al. (1998) construct a theoretical model to examine the impact of firm-level financial liberalization, namely cross-listing, on volatility where inter-market information is costly. Their model suggests that firm-level liberalization may either increase or decrease volatility in the local market, depending on the transparency of inter-market informational linkages. ${ }^{5}$

It is also crucial to know how the financial liberalization process influences the components of volatility because this improves our understanding of the driving forces of a potential change in the total volatility. The financial liberalization process can affect systematic and idiosyncratic components of volatility in different ways and through different motives, resulting in important implications for investors seeking diversification. A candidate explanation of a possible change in systematic volatility due to the process of finan-

\footnotetext{
${ }^{4}$ In his model, Merton (1987) assumes that existing investors in the market know only a subset of the available securities and that an investor includes a security in his portfolio only if he has information about this security. Merton theoretically shows that broadening the investor base in a market with this kind of incomplete information increases risk-sharing and lowers expected returns.

5 With freely available price information, some foreign investors who were previously unable to participate in the local market due to high entry costs enter the international market after cross-listing. This increases the total number of traders in both markets, and increases the analyst coverage and publicly available information flow, which in turn reduces variance of public information and thus decreases volatility. If information linkages are imperfect, then some investors may migrate from the local market to the international market, where they find it cheaper to trade resulting in an increase in volatility in the local market.
} 
cial liberalization may be the change in market dynamics that occurs when shifting from a segmented market to an integrated market. As the degree of financial liberalization in emerging markets increases and these markets become more integrated into global capital markets, exposure to local factors decreases (Foerster and Karolyi, 1999). Thus, global factors can play a more important role in determining the stock-return volatility. Given the high volatility of emerging markets (Harvey, 1995) and the more stable nature of the global market, in the transition from a segmented market to an integrated market a decrease in local volatility and an increase in global volatility are likely.

The liberalization process can also affect idiosyncratic volatility because of possible changes in the content and accuracy of information flow. Some studies report that increased financial analyst coverage associated with the increased degree of financial liberalization results in the production of firm-specific information (Lang and Lundholm, 1996). Existing literature also documents that trading on firm-specific information manifests itself as high levels of idiosyncratic volatility (see, for example, Xu and Malkiel, 2003). Hence, the financial liberalization process can reveal greater firm-specific information, causing idiosyncratic volatility to increase. Some other studies, however, argue that the added market participants associated with financial openness contribute to improve the precision of public information and to produce marketwide information rather than firm-specific information. ${ }^{6}$ Both of these actions have a decreasing impact on idiosyncratic volatility. Thus, the financial liberalization process may either increase or decrease firm-specific information flow, resulting in a higher or lower level of idiosyncratic volatility, depending on the type and accuracy of the information incorporated into stock prices. Therefore, the net influence of the degree of financial liberalization on idiosyncratic volatility is an empirical issue.

In summary, theoretical discussions provide mixed implications regarding the impact of financial liberalization on total volatility and its components; therefore the empirical investigation of this question is a worthwhile effort and will add to the literature by improving our understating of volatility dynamics.

\subsection{Constructing and decomposing aggregated total volatility}

In this section, we explain how to construct aggregated total volatility that is free of covariance and individual beta terms. Moreover, in order to separate the potential differential effects of the degree of financial liberalization on systematic and idiosyncratic volatility, we decompose aggregated total volatility into its constituents. Campbell et al. (2001) propose a novel method to decompose aggregated return volatility that does not require the estimation of covariances or individual beta terms. Ferreira and Gama use this approach to study the behavior of stock-return volatility from the perspective of a global investor. The results of both Campbell et al. (2001) and Ferreira and Gama (2005) emerge from separate adjusted models that occur at the same time, which may be restrictive. ${ }^{7}$ We extend the method of volatility decomposition introduced by Campbell et al. (2001) to a modified market model, where the returns of both the global market portfolio and the local market portfolio drive the return on stock $i$ of country $l$ in period $t$.

In integrated markets, stocks in the same risk class should provide the same risk-adjusted returns due to the no-arbitrage condition. However, in segmented markets similar stocks may yield

\footnotetext{
${ }^{6}$ For instance, Fernandes and Ferreira (2008) find that firm-level financial liberalization decreases price informativeness, measured by firm-specific return variation in emerging markets and Domowitz et al. (1998) show that variance of public information is inversely related to the number of market participants.

7 While Campbell et al. (2001) use market- and industry-adjusted models, Ferreira and Gama (2005) use world- and country-adjusted models.
}

different returns, since only national factors affect asset pricing. In most cases, local markets are open or partly open to foreign investor participation through financial liberalization but they have not yet completed their integration with the world markets and exhibit time-varying integration. ${ }^{8}$ Thus, many local markets are neither fully segmented nor fully integrated. Partial-segmentation theories handle such cases (see, among others, Errunza and Losq, 1985). The idea behind these theories is the following. In completely segmented markets, the benchmark portfolio in determining the prices of securities is the local market index portfolio. On the other hand, in fully integrated markets, securities will be priced to the global market index since only global factors affect pricing of these securities. In practice, markets are typically neither fully segmented nor fully integrated. In this case, the securities should be priced according both to the local and global market portfolios. Our extended modified market model aims to represent this partially segmented, partially integrated nature of many emerging markets. Decomposing the total volatility under this model not only enables us to examine the effects of the local and global factors simultaneously, but also to account for the conditional effect of one factor, given the other.

The details of the volatility decomposition methodology are as follows: we assume that the return on the global market portfolio is equal to the weighted average returns of the local market portfolios, i.e., $\sum_{l} w_{l t} R_{l t}=R_{w t}$, and that the return on the local market portfolio is the weighted average return of individual stocks in the country, that is, $\sum_{i} w_{i t} R_{i l t}=R_{l t}$. In addition, each local market portfolio contributes to the systematic risk of the global market portfolio, commensurate with its covariance with the global market portfolio. More specifically,

$\widetilde{R}_{l t}=\beta_{l w} \widetilde{R}_{w t}+\tilde{\varepsilon}_{l t}$.

We formulate the modified market model in an international framework as

$\widetilde{R}_{i l t}=\beta_{i w} \widetilde{R}_{w t}+\beta_{i l} \tilde{\varepsilon}_{l t}+\tilde{\varepsilon}_{i l t}$

where $\beta_{i w}=\operatorname{cov}\left(\widetilde{R}_{w t}, \widetilde{R}_{i l t}\right) / \operatorname{var}\left(\widetilde{R}_{w t}\right) ; \beta_{i l}=\operatorname{cov}\left(\widetilde{\varepsilon}_{l t}, \widetilde{R}_{i l t}\right) / \operatorname{var}\left(\widetilde{\varepsilon}_{l t}\right) ;$ and $\widetilde{R}_{l t}=\sum_{i \in l} w_{i t} \widetilde{R}_{i l t}$. Note that

$$
\begin{aligned}
\sum_{i \in l} w_{i t} \beta_{i w} & =\operatorname{cov}\left(\widetilde{R}_{w t}, \sum_{i \in l} w_{i t} \widetilde{R}_{i l t}\right) / \operatorname{var}\left(\widetilde{R}_{w t}\right) \\
& =\operatorname{cov}\left(\widetilde{R}_{w t}, \widetilde{R}_{l t}\right) / \operatorname{var}\left(\widetilde{R}_{w t}\right) \\
& =\operatorname{cov}\left(\widetilde{R}_{w t}, \beta_{l w} \widetilde{R}_{w t}+\widetilde{\varepsilon}_{l t}\right) / \operatorname{var}\left(\widetilde{R}_{w t}\right) \\
& =\left(\operatorname{cov}\left(\widetilde{R}_{w t}, \beta_{l w} \widetilde{R}_{w t}\right)+\operatorname{cov}\left(\widetilde{R}_{w t}, \widetilde{\varepsilon}_{l t}\right)\right) / \operatorname{var}\left(\widetilde{R}_{w t}\right) \\
& =\beta_{l w} \operatorname{cov}\left(\widetilde{R}_{w t}, \widetilde{R}_{w t}\right) / \operatorname{var}\left(\widetilde{R}_{w t}\right)=\beta_{l w},
\end{aligned}
$$

where $\operatorname{cov}\left(\widetilde{R}_{w t}, \tilde{\varepsilon}_{l t}\right)$ is zero, since $\widetilde{R}_{w t}$ and $\tilde{\varepsilon}_{l t}$ are orthogonal by construction.

Similarly,

$$
\begin{aligned}
\sum_{i \in l} w_{i t} \beta_{i l} & =\operatorname{cov}\left(\tilde{\varepsilon}_{l t}, \sum_{i \in l} w_{i t} \widetilde{R}_{i l t}\right) / \operatorname{var}\left(\tilde{\varepsilon}_{l t}\right)=\operatorname{cov}\left(\tilde{\varepsilon}_{l t}, \widetilde{R}_{l t}\right) / \operatorname{var}\left(\tilde{\varepsilon}_{l t}\right) \\
& =\operatorname{cov}\left(\tilde{\varepsilon}_{l t}, \beta_{l w} \widetilde{R}_{w t}+\tilde{\varepsilon}_{l t}\right) / \operatorname{var}\left(\tilde{\varepsilon}_{l t}\right) \\
& =\left(\operatorname{cov}\left(\tilde{\varepsilon}_{l t}, \beta_{l w} \widetilde{R}_{w t}\right)+\operatorname{cov}\left(\tilde{\varepsilon}_{l t}, \tilde{\varepsilon}_{l t}\right)\right) / \operatorname{var}\left(\tilde{\varepsilon}_{l t}\right) \\
& =\operatorname{cov}\left(\tilde{\varepsilon}_{l t}, \tilde{\varepsilon}_{l t}\right) / \operatorname{var}\left(\tilde{\varepsilon}_{l t}\right)=1,
\end{aligned}
$$

where $\operatorname{cov}\left(\tilde{\varepsilon}_{l t}, \beta_{l w} \widetilde{R}_{w t}\right)$ is zero, since $\widetilde{R}_{w t}$ and $\tilde{\varepsilon}_{l t}$ are orthogonal by construction.

In volatility decomposition, we aim to reach covariance and stock beta-free components. Thus we do not have to estimate these parameters which may not be constant and precise over time. For

\footnotetext{
${ }^{8}$ See, for instance, Bekaert and Harvey (1995), Bekaert and Harvey (2002).
} 
this purpose, we introduce the following market-adjusted model, as suggested by Campbell et al. (2001):

$\widetilde{R}_{i l t}=\widetilde{R}_{l t}+\varepsilon_{i l t}$.

Inserting (1) into (3),

$\widetilde{R}_{i l t}=\beta_{l w} \widetilde{R}_{w t}+\tilde{\varepsilon}_{l t}+\varepsilon_{i l t}$.

Here, the return on stock $i$ of country $l$ is the sum of the return on the global market portfolio multiplied by $\beta_{l w}$, a country-specific shock and a firm-specific residual. ${ }^{9}$ Equating (2) to (4) produces the following equality that shows in which channel the two equations are connected:

$\varepsilon_{i l t}=\left(\beta_{i w}-\beta_{l w}\right) \widetilde{R}_{w t}+\left(\beta_{i l}-1\right) \tilde{\varepsilon}_{l t}+\tilde{\varepsilon}_{i l t}$.

Taking the variance of (4) yields

$$
\begin{aligned}
\operatorname{var}\left(\widetilde{R}_{i l t}\right)= & \beta_{l w}^{2} \operatorname{var}\left(\widetilde{R}_{w t}\right)+\operatorname{var}\left(\tilde{\varepsilon}_{l t}\right)+\operatorname{var}\left(\varepsilon_{i l t}\right)+2 \beta_{l w} \operatorname{cov}\left(\widetilde{R}_{w t}, \varepsilon_{i l t}\right) \\
& +2 \operatorname{cov}\left(\widetilde{\varepsilon}_{l t}, \varepsilon_{i l t}\right) .
\end{aligned}
$$

Inserting (5) into (6) for covariance terms only yields

$$
\begin{aligned}
\operatorname{var}\left(\widetilde{R}_{i l t}\right)= & \beta_{l w}^{2} \operatorname{var}\left(\widetilde{R}_{w t}\right)+\operatorname{var}\left(\tilde{\varepsilon}_{l t}\right)+\operatorname{var}\left(\varepsilon_{i l t}\right) \\
& +2 \operatorname{cov}\left(\widetilde{R}_{w t},\left(\beta_{i w}-\beta_{l w}\right) \widetilde{R}_{w t}+\left(\beta_{i l}-1\right) \tilde{\varepsilon}_{l t}+\tilde{\varepsilon}_{i l t}\right) \\
& +2 \operatorname{cov}\left(\tilde{\varepsilon}_{l t},\left(\beta_{i w}-\beta_{l w}\right) \widetilde{R}_{w t}+\left(\beta_{i l}-1\right) \tilde{\varepsilon}_{l t}+\tilde{\varepsilon}_{i l t}\right) .
\end{aligned}
$$

Rearranging (7),

$\operatorname{var}\left(\widetilde{R}_{i l t}\right)=\left(2 \beta_{l w} \beta_{i w}-\beta_{l w}^{2}\right) \operatorname{var}\left(\widetilde{R}_{w t}\right)+\left(2 \beta_{i l}-1\right) \operatorname{var}\left(\tilde{\varepsilon}_{l t}\right)+\operatorname{var}\left(\varepsilon_{i l t}\right)$.

Taking the weighted averages of (8) over $i$ and substituting $\beta_{l w}$ for $\sum_{i \in l} w_{i t} \beta_{i w}$ and 1 for $\sum_{i \in l} w_{i t} \beta_{i l}$ yield the following:

$$
\begin{aligned}
\sum_{i \in l} w_{i t} \operatorname{var}\left(\widetilde{R}_{i l t}\right)=(2 & \left.\beta_{l w} \sum_{i \in l} w_{i t} \beta_{i w}-\beta_{l w}^{2}\right) \operatorname{var}\left(\widetilde{R}_{w t}\right) \\
+ & \operatorname{var}\left(\tilde{\varepsilon}_{l t}\right)\left(2 \sum_{i \in l} w_{i t} \beta_{i l}-1\right)+\sum_{i \in l} w_{i t} \operatorname{var}\left(\varepsilon_{i l t}\right) \\
= & \beta_{l w}^{2} \operatorname{var}\left(\widetilde{R}_{w t}\right)+\operatorname{var}\left(\tilde{\varepsilon}_{l t}\right)+\sum_{i \in l} w_{i t} \operatorname{var}\left(\varepsilon_{i l t}\right)
\end{aligned}
$$

$\sigma_{a_{l t}}^{2}=\sigma_{w_{l t}}^{2}+\sigma_{\varepsilon_{l t}}^{2}+\sigma_{\varepsilon_{i l t}}^{2}$,

where $\sigma_{a_{l t}}^{2}=\sum_{i \in l} w_{i t} \operatorname{var}\left(\widetilde{R}_{i l t}\right), \sigma_{w_{l t}}^{2}=\beta_{l w}^{2} \operatorname{var}\left(\widetilde{R}_{w t}\right), \sigma_{\varepsilon_{l t}}^{2}=\operatorname{var}\left(\tilde{\varepsilon}_{l t}\right)$, and $\sigma_{\varepsilon_{i l t}}^{2}=\sum_{i \in l} w_{i t} \operatorname{var}\left(\varepsilon_{i l t}\right)$.

The aggregated return volatility of stocks in a country is a representation of the return volatility of a typical firm in that country. Eq. (9) shows that the total volatility of a typical firm in a country is composed of global, local and aggregated idiosyncratic volatility. The volatility components in Eq. (9) do not contain covariance and stock beta terms. The only beta term in this equation, $\beta_{l w}$, is the beta of the local market portfolio with respect to the global market portfolio. Fama and MacBeth (1973) mention that estimated portfolio betas are much more precise estimates of the true betas than the beta estimates of individual securities. Thus, we minimize the estimation problems of the components of aggregated total volatility in a country.

In assessing the impact of the degree of financial liberalization, we are primarily interested in aggregated volatilities of individual stocks rather than the volatility of a local market portfolio. The reason for this focus is that country index volatility is composed both of individual stock-return variances and pair-wise covariances of stock returns. Therefore, studies analyzing the return volatility of country indices do not fully explain the behavior of average

\footnotetext{
${ }^{9}$ Eq. (2) is equivalent to Eq. (4) whenever $\beta_{i l}=1$ and $\beta_{i w}=\beta_{l w}$. Thus, Eq. (4) represents a simplified return-generating process of an average firm in a country. We thank Frank de Jong for bringing this issue to our attention.
}

stock-return volatilities. The aggregated volatility used in this study clearly demonstrates the effects of external factors on the return volatility of an average stock.

\section{Data and methodology}

Our main data sources in this study are Standard \& Poor's Emerging Markets Database (EMDB) and Datastream. Our data comprise returns of stocks that are listed in Standard \& Poor's/International Finance Corporation's (SP/IFC) global index of emerging markets. ${ }^{10}$ All SP/IFC global index firms in the specific emerging markets form our sample. The research period extends from 1991 to 2005. For each year of the research period, we compute the annual return variances of firms listed in the SP/IFC global index of the EMDB by using the weekly adjusted closing prices. In calculating the weighted averages of return variances, we use the weights based on the market capitalizations of the indexed firms, which are also extracted from the EMDB. We compute the return variance of the global index, $\operatorname{var}\left(\widetilde{R}_{w t}\right)$ of Eq. (9), by using the closing prices of the global index drawn from Datastream. The closing prices of the local index, which is the SP/IFC global index of the emerging markets, come from EMDB.

We proxy the degree of financial liberalization by several measures proposed in the literature. We categorize these measures in two groups: restriction-based and capital flow-based. Each group has strengths and weaknesses. The advantage of restriction-based measures is that they are direct depictions of government restrictions. However, restriction-based measures may suffer from a lack of accurate quantification of the intensity of the government restrictions due to the binary classification used in constructing these measures. On the other hand, empirical studies also use measures of international capital flows to proxy for financial openness. Although capital flow-based measures are strong in representing the intensity of the openness, they may be weak as exogenous drivers of volatility since volatility may itself affect capital flows. In this study, we use variables belonging to both groups of measures for the degree of financial liberalization rather than focusing on one measure or one group of measures. In this way, we can observe whether different measures of the degree of financial liberalization lead to different results.

We first proxy the degree of financial liberalization by a capital flow-based measure proposed by Lane and Milesi-Ferretti (2007). Their measure ( $L M F$ hereafter) is the sum of a country's foreign equity assets and liabilities and the foreign direct investment assets and liabilities as a share of the GDP. ${ }^{11}$ The idea behind using this measure as a proxy is that the level of capital flows signals the extent to which an economy restricts cross-border transactions. We also propose a variant of $L M F$ that focuses on the foreign equity liabilities dimension. Foreign equity liabilities $(F E L)$ represent the value of foreign equity portfolio in a local stock exchange. Thus, the ratio of the value of the foreign equity portfolio to the market capitalization of a local stock exchange provides an indication of the openness of a local stock exchange to foreign equity investment. We obtain the data for constructing $L M F$ and FEL from the External Wealth of Nations Mark II database.

Chin and Ito (2007) introduce an index aimed at measuring the extent of openness in capital controls based on information from the IMF's Annual Report on Exchange Arrangements and Exchange Restrictions (AREAER). They use a binary coding system to transform information about the liberty of cross-border financial

\footnotetext{
10 The SP/IFC global index aims to represent $70-80 \%$ of the total market capitalization of the local stock exchange. Index-constituent firms are chosen to reflect the local market's best, and therefore, the composition of the index may change over time.

11 In other words, $L M F$ is equal to a country's foreign equity inflows and outflows
} plus foreign direct investment (FDI) inflows and outflows divided by GDP. 
transactions into a quantitative scale. Their restriction-based index takes on higher values the more open a country is to cross-border capital transactions. In their study, Chin and Ito (2007) make this index publicly available, and we name it as $C I$ in our study.

Finally, for the equity market liberalization we use the measure of Edison and Warnock (2003). Edison and Warnock (2003) define this measure as the ratio of market capitalizations of a country's SP/IFC investible index to its SP/IFC global index, both of which can be compiled from the EMDB. For each emerging market, SP/ IFC computes a global index that aims to proxy the whole market. SP/IFC also computes an investible index that shows the accessible portion of the market to foreign investors. The ratio of the market capitalization of SP/IFC investible index to that of SP/IFC global index gives a measure of the accessibility of the stock exchange to foreigner investors. This ratio ( $E W$ hereafter) lies between zero (the inaccessible case) and one (the fully accessible case).

Making use of the above measures for the degree of financial liberalization brings unique advantages to our study. These measures allow us to model financial liberalization as a quantitative continuous variable and to observe changes in the financial openness of emerging markets through time. Thus, rather than a binary measure of financial liberalization (liberalized/non-liberalized), we have more accurate continuous measures of the degree of financial liberalization. Hence, we eliminate the previously discussed dating of the liberalization problem by incorporating the time-varying nature of the liberalization process.

We analyze the impact of the degree of financial liberalization on aggregated total volatility and its components under the control of some volatility determinants. ${ }^{12}$ We introduce the turnover variable, $T O$, to control for liquidity effects. We define TO as the total value of shares traded during the period divided by the average market capitalization for the period, calculated in local currency. Average market capitalization is the mean of the end-of period values for the current period and the previous period. In order to account for the effect of the stock market's development on the volatility, we use the variable Size, which is defined as the ratio of market capitalization of the stock market to the country's GDP. We download the data for the control variables from EMDB except for the GDP data; we obtain GDP data from the World Bank.

\subsection{Estimation of volatility and volatility components}

We estimate the aggregated total volatility and its components in the following manner. Let $s$ refer to weeks over which returns are calculated and $t$ refer to the year in which the volatility estimates are constructed. We compute the annual volatility of a stock in country $l$ as

$\operatorname{var}\left(\widetilde{R}_{\text {ilt }}\right)=\sum_{s \in t}\left(R_{\text {ils }}-\mu_{\text {ilt }}\right)^{2}$,

where $\mu_{i l t}$ is the mean return of stock $i$ in country $l$ at time $t$. The weighted average of return volatilities of all stocks in the SP/IFC global index of country $l$ in year $t$ forms the aggregated total volatility measure for that year.

$\sum_{i \in l} w_{i t} \operatorname{var}\left(\widetilde{R}_{i l t}\right)=\sum_{i \in l} w_{i t}\left(\sum_{s \in t}\left(R_{i l s}-\mu_{i l t}\right)^{2}\right)$.

The weight for each firm is the ratio of market capitalization of the firm to that of the stock exchange in which it belongs. Next, we estimate the components of aggregated total volatility that are based on the dollar returns. For instance, we estimate global volatility (Global) within period $t$ as follows:

\footnotetext{
12 See Bekaert and Harvey (2000) for a set of explanatory variables for volatility at the aggregate level.
}

Global $=\hat{\sigma}_{w t}^{2}=\hat{\beta}_{l w}^{2}\left(\sum_{s \in t}\left(R_{w s}-\mu_{w t}\right)^{2}\right)$,

where $\hat{\beta}_{l w}$ is the estimated regression coefficient of Eq. (1) within a year, calculated from the weekly return data, and $\mu_{w t}$ is the mean of the global index return. We compute the local volatility, the variance of the local index return that is isolated from the global index return, by summing up the squares of the country-specific residuals of Eq. (1) within period $t$. More explicitly,

Local $=\hat{\sigma}_{\varepsilon_{l t}}^{2}=\sum_{s \in t} \hat{\varepsilon}_{s}^{2}$.

For estimating the idiosyncratic volatility component, first we sum up the squares of the firm-specific residuals of Eq. (3) for each firm within period $t$ :

$\operatorname{vâr}_{\varepsilon_{i l t}}=\sum_{s \in t} \hat{\varepsilon}_{i l s}^{2}$.

Then we aggregate Eq. (14) over firms in a market to reach valueweighted idiosyncratic volatility estimates, as follows:

Idiosyncratic $=\hat{\sigma}_{\varepsilon_{\text {lt }}}^{2}=\sum_{i \in l} w_{i t} \operatorname{vâr}\left(\varepsilon_{i l t}\right)$.

\subsection{Descriptive statistics}

We provide the descriptive information for volatility measures, the degree of financial liberalization measures and the control variables in Table 1. We present the time-series means of each variable for each country in the body of the table. The bottom rows show the preliminary statistics for the overall sample. Out of the emerging countries in this study, Argentina, Brazil, the Czech Republic, Hungary, Indonesia, Israel, Mexico, Peru and Poland have the most liberal stock exchanges, with FEL and $E W$ measures that are higher than the sample average. Argentina, the Czech Republic, Hungary, Indonesia, Israel, Jordan, Malaysia, Mexico, Peru and Philippines are the countries that are relatively more open in terms of capital account restrictions. Finally Chile, the Czech Republic, Hungary, Israel, Malaysia, Russia, South Africa, Taiwan and Thailand are the most liberal capital markets when cross-border transactions in terms of portfolio equity investment and foreign direct investment are considered.

The mean level of volatility components for the overall sample in Table 1 shows that Idiosyncratic represents the largest share of total volatility, with a mean level of 0.144 . Local makes the second largest contribution, with a mean level of 0.110 . The smallest contribution to the total volatility comes from Global, with a 0.017 mean level. At the country level, Argentina, Poland and Turkey are the only exceptions that have a greater local volatility than idiosyncratic volatility.

\section{Aggregated total volatility and the degree of financial liberalization}

In this section, we first examine whether the degree of financial liberalization has an impact on the aggregated total volatility of stocks, $\sum_{i \in l} w_{i t} \operatorname{var}\left(\widetilde{R}_{i t}\right)=\sigma_{\text {alt }}^{2}$. In Section 5, we explore channels through which the degree of financial liberalization can impact aggregated total volatility.

We regress $\log \hat{\sigma}_{\text {alt }}^{2}$ on the degree of financial liberalization under the control of liquidity, market development, crises and fixed country effects in a panel setting: ${ }^{13}$

$$
\begin{aligned}
\log \hat{\sigma}_{\text {alt }}^{2}= & \alpha+\beta_{1} \text { Finlib }_{l t}+\beta_{2} \text { TO }_{l t}+\beta_{3} \text { Size }_{l t}+\beta_{4} \text { AsianCrisis }_{t} \\
& +\beta_{5} \text { PesoCrisis }_{t}+\text { country }_{l}+\eta_{l t} .
\end{aligned}
$$

\footnotetext{
${ }^{13}$ In order to have a dependent variable that is approximately normal in distribution, we use the logarithmic transformation of aggregated total volatility
} 
Table 1

Descriptive statistics.

\begin{tabular}{|c|c|c|c|c|c|c|c|c|c|c|}
\hline & Aggregated total volatility & Idiosyncratic & Local & Global & LMF & IC & FEL & EW & TO & Size \\
\hline Argentina & 0.279 & 0.128 & 0.133 & 0.022 & 0.319 & 0.695 & 0.297 & 0.942 & 0.271 & 0.315 \\
\hline Brazil & 0.386 & 0.209 & 0.151 & 0.035 & 0.271 & -0.983 & 0.353 & 0.843 & 0.413 & 0.310 \\
\hline Chile & 0.108 & 0.066 & 0.034 & 0.009 & 0.748 & -0.289 & 0.113 & 0.903 & 0.100 & 0.923 \\
\hline China & 0.322 & 0.152 & 0.140 & 0.005 & 0.221 & -1.130 & 0.199 & 0.672 & 1.480 & 0.247 \\
\hline Colombia & 0.168 & 0.098 & 0.066 & 0.003 & 0.186 & -1.125 & 0.123 & 0.243 & 0.087 & 0.151 \\
\hline Czech Rep. & 0.165 & 0.096 & 0.053 & 0.009 & 0.422 & 1.689 & 0.489 & 0.746 & 0.515 & 0.222 \\
\hline Hungary & 0.186 & 0.098 & 0.072 & 0.022 & 0.506 & 1.182 & 0.290 & 0.886 & 0.587 & 0.201 \\
\hline India & 0.222 & 0.142 & 0.070 & 0.006 & 0.090 & -1.060 & 0.220 & 0.378 & 1.232 & 0.364 \\
\hline Indonesia & 0.441 & 0.215 & 0.190 & 0.035 & 0.127 & 1.773 & 0.330 & 0.715 & 0.427 & 0.233 \\
\hline Israel & 0.129 & 0.077 & 0.042 & 0.012 & 0.546 & 1.423 & 0.432 & 0.989 & 0.492 & 0.585 \\
\hline Jordan & 0.063 & 0.042 & 0.024 & 0.000 & 0.334 & 1.061 & 0.009 & 0.363 & 0.235 & 0.940 \\
\hline Korea & 0.305 & 0.164 & 0.120 & 0.029 & 0.228 & -0.436 & 0.267 & 0.632 & 2.094 & 0.504 \\
\hline Malaysia & 0.198 & 0.105 & 0.077 & 0.013 & 0.791 & 0.713 & 0.232 & 0.825 & 0.417 & 1.742 \\
\hline Mexico & 0.211 & 0.129 & 0.058 & 0.026 & 0.280 & 0.877 & 0.344 & 0.898 & 0.335 & 0.282 \\
\hline Morocco & 0.051 & 0.032 & 0.020 & 0.001 & 0.280 & -1.130 & 0.115 & 0.776 & 0.096 & 0.326 \\
\hline Pakistan & 0.217 & 0.129 & 0.082 & 0.001 & 0.087 & -1.174 & 0.253 & 0.674 & 1.295 & 0.125 \\
\hline Peru & 0.151 & 0.104 & 0.048 & 0.006 & 0.328 & 2.251 & 0.394 & 0.882 & 0.204 & 0.219 \\
\hline Philippines & 0.189 & 0.109 & 0.062 & 0.015 & 0.245 & 0.129 & 0.220 & 0.503 & 0.231 & 0.548 \\
\hline Poland & 0.283 & 0.120 & 0.144 & 0.022 & 0.197 & -0.492 & 0.345 & 0.987 & 0.588 & 0.134 \\
\hline Russia & 0.561 & 0.275 & 0.206 & 0.071 & 0.348 & -0.683 & 0.423 & 0.594 & 0.306 & 0.390 \\
\hline S. Africa & 0.167 & 0.105 & 0.045 & 0.020 & 0.716 & -0.941 & 0.178 & 0.991 & 0.285 & 1.673 \\
\hline Taiwan & 0.178 & 0.088 & 0.081 & 0.012 & 0.465 & NA & 0.130 & 0.424 & 2.512 & 0.936 \\
\hline Thailand & 0.278 & 0.147 & 0.106 & 0.026 & 0.353 & -0.089 & 0.420 & 0.436 & 0.834 & 0.546 \\
\hline Turkey & 0.571 & 0.251 & 0.289 & 0.024 & 0.108 & -0.783 & 0.210 & 0.978 & 1.395 & 0.190 \\
\hline Zimbabwe & 1.039 & 0.556 & 0.463 & 0.011 & 0.177 & -1.397 & 0.000 & 0.229 & 0.107 & 0.305 \\
\hline Mean & 0.272 & 0.144 & 0.110 & 0.017 & 0.335 & 0.003 & 0.255 & 0.706 & 0.723 & 0.511 \\
\hline Std. Dev. & 0.363 & 0.168 & 0.183 & 0.043 & 0.200 & 1.125 & 0.130 & 0.301 & 0.881 & 0.513 \\
\hline Minimum & 0.032 & 0.021 & 0.007 & 0.000 & 0.791 & 2.251 & 0.489 & 0.000 & 0.002 & 0.021 \\
\hline Maximum & 3.457 & 1.616 & 1.888 & 0.493 & 0.087 & -1.397 & 0.000 & 1.000 & 4.974 & 3.294 \\
\hline
\end{tabular}

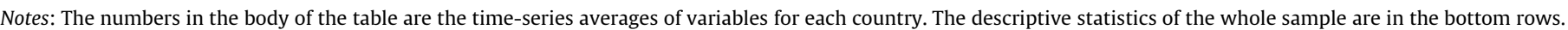

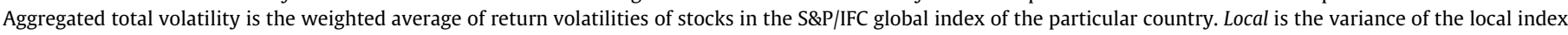

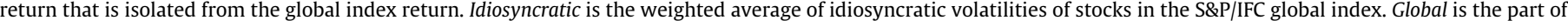

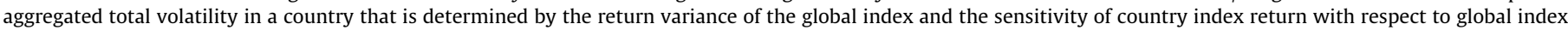

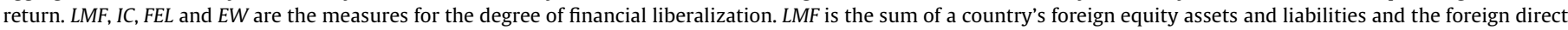

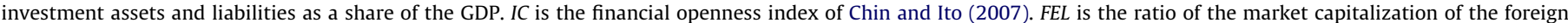

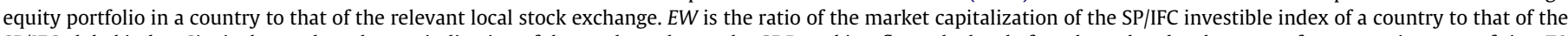

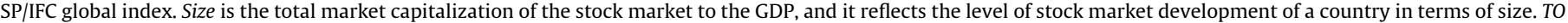
is the total value of shares traded in the market during the period, divided by the average market capitalization for the period, and it accounts for the liquidity effects.

Finlib $_{l t}$ is one of the four measures of the degree of financial liberalization ( $L M F, I C, F E L, E W)$ of country $l$ in time $t$ that are mentioned previously and is the focus of interest in this study. As Bekaert and Harvey (2000) suggest, volatility may exhibit different patterns as the stock market becomes more developed and mature. With this in mind, we include the Size control variable measured by the total market capitalization of the stock market to the GDP, aiming to reflect the level of market development. Moreover, we account for the effects of liquidity measured by the turnover ratio, TO, in terms of value traded. Given that the research period covers major crises such as the Mexican Peso, Asian and Russian crises, and that the volatility in a country is likely to be affected during these times, we include time dummies in the model in order to account for crisis-year effects. Asian-RussianCrisis is a combined dummy variable which represents the Asian and Russian crises that occurred in 19981999 and 1999, respectively, and takes the value of one for all countries for 1998 and 1999, and zero otherwise. PesoCrisis takes the value of one for Latin American countries for the years 1994 and 1995. country $_{l}$ is a country-specific dummy variable and controls for unobserved country effects that may drive volatility.

Table 2 presents the estimated results of the panel regression above. Each column of the table shows the results of a different specification that includes one of the measures of the degree of financial liberalization ( $L M F, I C, F E L$ and $E W)$. In all specifications, we include country dummies but do not report the estimates. The regressions allow for panel-specific heteroskedasticity and serial correlation. In all specifications, we document a persistent statistically significant negative effect of the degree of financial liberalization on aggregated total volatility. These findings reveal that as the degree of financial liberalization increases, aggregated total volatility decreases. For instance, if the degree of financial liberalization measures increase by 0.10 , then aggregated total volatility decreases by a minimum of $1.5 \%$ (for $I C$ ) to a maximum of 9\% (for $F E L$ ) per year, depending on the liberalization measure. The signs of the control variables are in line with the findings of the previous literature. While turnover is positively associated with aggregated total volatility, the development stage of the stock market is negatively associated. Both of the crisis dummies are significantly positive, suggesting that during crisis times aggregated total volatility increases. Our finding of decreasing volatility as the markets get more liberalized is consistent with the implications of the extended investor-base broadening hypothesis, which suggests a reduction in volatility due to the increased precision of public information.

\subsection{Binary modeling of financial liberalization by accounting for different types of liberalization}

Some countries, such as Argentina, Chile, Hungary, Poland, South Africa and Turkey, adopted intense financial liberalization. Either these countries liberalized their stock exchanges fully one at a time or they became fully open to foreign investors in a few years after the initial liberalization. Other countries, such as Philippines, Peru and Jordan partly opened their stock exchanges to foreigners in the beginning of liberalization process, but did not exhibit a notable change in the intensity of capital controls 
Table 2

Aggregated total volatility and the degree of financial liberalization.

\begin{tabular}{lllll}
\hline LMF & $-0.349^{* *}$ & & \\
IC & $(2.120)$ & & \\
& & $-0.151^{* * *}$ & & \\
FEL & & $(4.799)$ & & \\
& & & \\
EW & & & $(4.620)$ & \\
& & & $-0.305^{* * *}$ \\
TO & & & & $(2.028)$ \\
& & & & \\
Size & $0.123^{* * *}$ & $0.106^{* *}$ & $0.141^{* * *}$ & $0.185^{* * *}$ \\
& $(2.676)$ & $(2.213)$ & $(3.276)$ & $(3.510)$ \\
Asian-RussianCrisis & $-0.243^{* *}$ & -0.166 & $-0.305^{* *}$ & $-0.597^{* * *}$ \\
& $(1.745)$ & $(1.289)$ & $(2.558)$ & $(4.544)$ \\
PesoCrisis & $0.585^{* * *}$ & $0.591^{* * *}$ & $0.552^{* * *}$ & $0.584^{* * *}$ \\
& $(8.137)$ & $(8.233)$ & $(7.814)$ & $(8.558)$ \\
Country fixed effects & $0.444^{* * *}$ & $0.450^{* * *}$ & $0.389^{* * *}$ & $0.517^{* * *}$ \\
Ad. $R^{2}$ & $(3.175)$ & $(3.362)$ & $(2.808)$ & $(3.925)$ \\
& Yes & Yes & Yes & Yes \\
& 0.530 & 0.579 & 0.554 & 0.607 \\
\hline
\end{tabular}

Notes: The results correspond to regression Eq. (16) in the study. The dependent variable is the logarithmic transformation of aggregated total volatility, where aggregated total volatility is the weighted average of weekly return volatilities of stocks in the S\&P/IFC global index of the relevant emerging countries. The degree of financial liberalization measures ( $L M F, I C, F E L$ and $E W$ ) and the control variables (TO, Size) are as defined in Table 1. Country fixed effects are the country-specific dummy variables. Asian-RussianCrisis and PesoCrisis dummy variables take the value of one in 1998 and 1999 for all countries and in 1994 and 1995 for Latin American countries, respectively. The results of regression models in which the degree of financial liberalization is represented by different measures ( $L M F, I C, F E L$ and $E W$ ) are presented in separate columns. The regressions allow for panel-specific heteroskedasticity and serial correlation. The numbers in parentheses are $t$-statistic values.

Represents $10 \%$ significance level.

** Represents 5\% significance level.

*** Represents $1 \%$ significance level

thereafter. Another group of countries, such as Brazil, China, Colombia, the Czech Republic, India, Indonesia, Korea, Malaysia, Mexico, Pakistan, Russia, Taiwan, Thailand and Zimbabwe, exhibit gradual variation in the degree of financial liberalization. ${ }^{14}$ Most of the previous studies examining the effects of financial liberalization, pool the countries in their analyses without considering the differences in the speed and intensity of financial liberalization. In other words, these studies implicitly assume that the effects of financial liberalization are the same for all emerging markets. However, given the large heterogeneity in the intensity of financial liberalization across liberalizing countries (see the measures for the degree of financial liberalization in Table 1) it is likely to observe differences in effects of financial liberalization on volatility.

In this section, we revisit the binary modeling of financial liberalization employed in previous literature by accounting for different intensities of liberalization across countries. We incorporate the information regarding the intensity of capital controls to the event-window analysis of financial liberalization by using Edison and Warnock's (2003) econometric methodology, which distinguishes partial liberalizations from more complete ones by interacting the time dummies for the post- and after-liberalization periods with the degree of financial liberalization measures. Accounting for the degree of financial liberalization in this manner facilitates relaxing the restrictive assumption that different types of liberalization have a common impact on volatility. Thus, we are able to examine whether complete and partial liberalizations affect volatility differently.

\footnotetext{
14 For a graphical representation of the foreign ownership restrictions through time for emerging markets, see Edison and Warnock (2003).
}

As in the previous sections of this study, we also examine the behavior of aggregated total volatility rather than market index volatility. However, unlike the previous sections we use an event-window methodology, taking the official liberalization dates of Bekaert and Harvey (2000) and Dvorak and Podpiera (2006) as the event dates. Thus, we check whether previously reported results for the continuous modeling of liberalization are also valid for the binary modeling of liberalization. Similar results obtained under two different models may provide evidence in favor of the view that a persistent relationship exists between volatility and financial liberalization as far as average stock-return volatility (aggregated total volatility) is concerned. This section also addresses the question of how long it takes for volatility to reach its new level after the initial relaxations of the restrictions. We compare the level of volatility in the pre-liberalization period to that in the post-liberalization period. Different durations for post-liberalization periods are introduced in order to determine when a significant difference in the level of volatility occurs between the pre- and post-liberalization periods for the first time. Finally, since the research period of this section differs from that of the previous sections, the results of this section provide a robustness check to see how previously reported results depend on time. The research period for event-window analysis of financial liberalization changes by country. It starts in 1984 at the earliest (for Argentina) and ends in 2005 (for Chile). This period also includes the times when markets are not liberalized at all because we compare the levels of volatility before and after liberalization. Comparatively, the previous sections focus on changes to the extent of financial liberalization and therefore examine the period after 1990, by which time all emerging markets in the study were liberalized.

We employ the econometric framework proposed by Edison and Warnock (2003) to distinguish the effects of partial and complete liberalizations. We estimate two sets of regressions for comparison purposes. The first regression specification does not distinguish between partial and complete liberalizations and pools all types of liberalizations. Rather than estimating aggregated total volatility (the dependent variable) for calendar years as we do in the previous sections, we estimate it for the years relative to the year of liberalization for each emerging market in this section. The explanatory variables are time dummies that take the value of one in the Pre (1 year prior to the year that includes the official liberalization date as the mid-year), During (the year that includes the official liberalization date as the mid-year, i.e., the year that extends from six months before and six months after liberalization), Post (from 1 to 2-4 years after the year of liberalization, depending on the window length of the post period), or After period (from the end of the Post period to 12 years after the year of liberalization). ${ }^{15}$ More specifically, the baseline regression model has the following form:

$\log \hat{\sigma}_{\text {alt }}^{2}=\alpha_{l}+\beta_{1}$ Pre $_{l t}+\beta_{2}$ During $_{l t}+\beta_{3}$ Post $_{l t}+\beta_{4}$ After $_{l t}+\varepsilon_{l t}$.

In estimating the above regression, we allow for panel-specific heteroskedasticity and serial correlation. The results of this specification show us how aggregated total volatility behaves around the implementation date of an average liberalization. The second regression specification distinguishes between partial and complete liberalizations by incorporating the change in the degree

\footnotetext{
15 Different from Edison and Warnock (2003), we use annual data since changes in the degree of financial liberalization are tracked at the annual frequency for all our measures of the degree of financial liberalization except $E W$. Therefore, we express the event windows in terms of years relative to the year of liberalization.
} 
Table 3

Incorporating the continuous measures of the degree of financial liberalization to binary modeling of financial liberalization.

\begin{tabular}{|c|c|c|c|c|c|c|}
\hline & Pre & During & Post & After & Wald (pre-post) & Wald (pre-after) \\
\hline \multicolumn{7}{|c|}{ Panel A: The window length of the post period is 2 years } \\
\hline Baseline & $\begin{array}{l}0.209 \\
(1.176)\end{array}$ & $\begin{array}{l}0.016 \\
(0.090)\end{array}$ & $\begin{array}{l}-0.124 \\
(-0.890)\end{array}$ & $\begin{array}{l}-0.199^{* *} \\
(-2.036)\end{array}$ & $\begin{array}{l}3.027 \\
{[0.082]}\end{array}$ & $\begin{array}{l}6.193 \\
{[0.013]}\end{array}$ \\
\hline With $L M F$ & $\begin{array}{l}0.261 \\
(1.558)\end{array}$ & $\begin{array}{l}0.072 \\
(0.430)\end{array}$ & $\begin{array}{l}0.055 \\
(0.107)\end{array}$ & $\begin{array}{l}-0.371^{* *} \\
(-2.224)\end{array}$ & $\begin{array}{l}0.163 \\
{[0.686]}\end{array}$ & $\begin{array}{l}10.012 \\
{[0.002]}\end{array}$ \\
\hline With IC & $\begin{array}{l}0.356^{*} \\
(1.941)\end{array}$ & $\begin{array}{l}0.168 \\
(0.913)\end{array}$ & $\begin{array}{l}-0.193^{*} \\
(-1.882)\end{array}$ & $\begin{array}{l}-0.240 \\
(-4.723)\end{array}$ & $\begin{array}{l}6.613 \\
{[0.010]}\end{array}$ & $\begin{array}{l}9.630 \\
{[0.002]}\end{array}$ \\
\hline With FEL & $\begin{array}{l}0.183 \\
(1.105)\end{array}$ & $\begin{array}{l}-0.015 \\
(-0.091)\end{array}$ & $\begin{array}{l}-0.8280 \\
(-1.003)\end{array}$ & $\begin{array}{l}-1.197^{* * *} \\
(-3.855)\end{array}$ & $\begin{array}{l}1.558 \\
{[0.212]}\end{array}$ & $\begin{array}{l}20.647 \\
{[0.000]}\end{array}$ \\
\hline With EW & $\begin{array}{l}0.153 \\
(0.900)\end{array}$ & $\begin{array}{l}-0.042 \\
(-0.246)\end{array}$ & $\begin{array}{l}-0.149 \\
(-0.813)\end{array}$ & $\begin{array}{l}-0.445^{* * *} \\
(-3.819)\end{array}$ & $\begin{array}{l}1.929 \\
{[0.165]}\end{array}$ & $\begin{array}{l}12.644 \\
{[0.000]}\end{array}$ \\
\hline \multicolumn{7}{|c|}{ Panel B: The window length of the post period is 3 years } \\
\hline Baseline & $\begin{array}{l}0.211 \\
(1.193)\end{array}$ & $\begin{array}{l}0.018 \\
(0.103)\end{array}$ & $\begin{array}{l}-0.103 \\
(-0.833)\end{array}$ & $\begin{array}{l}-0.216^{* *} \\
(-2.180)\end{array}$ & $\begin{array}{l}3.048 \\
{[0.081]}\end{array}$ & $\begin{array}{l}6.744 \\
{[0.009]}\end{array}$ \\
\hline With $L M F$ & $\begin{array}{l}0.267 \\
(1.592)\end{array}$ & $\begin{array}{l}0.078 \\
(0.463)\end{array}$ & $\begin{array}{l}-0.029 \\
(-0.069)\end{array}$ & $\begin{array}{l}-0.369^{* *} \\
(-2.234)\end{array}$ & $\begin{array}{l}0.500 \\
{[0.480]}\end{array}$ & $\begin{array}{c}10.224 \\
{[0.001]}\end{array}$ \\
\hline With IC & $\begin{array}{l}0.355^{*} \\
(1.933)\end{array}$ & $\begin{array}{l}0.169 \\
(0.920)\end{array}$ & $\begin{array}{l}-0.207^{* *} \\
(-2.303)\end{array}$ & $\begin{array}{l}-0.242^{* * * *} \\
(-4.637)\end{array}$ & $\begin{array}{l}7.317 \\
{[0.007]}\end{array}$ & $\begin{array}{l}9.597 \\
{[0.002]}\end{array}$ \\
\hline With FEL & $\begin{array}{l}0.190 \\
(1.143)\end{array}$ & $\begin{array}{l}-0.008 \\
(-0.048)\end{array}$ & $\begin{array}{l}-0.695 \\
(-0.987)\end{array}$ & $\begin{array}{l}-1.199 \\
(-3.858)\end{array}$ & $\begin{array}{l}1.671 \\
{[0.196]}\end{array}$ & $\begin{array}{l}20.888 \\
{[0.000]}\end{array}$ \\
\hline With EW & $\begin{array}{l}0.161 \\
(0.958)\end{array}$ & $\begin{array}{l}-0.036 \\
(-0.215)\end{array}$ & $\begin{array}{l}-0.156 \\
(-0.992)\end{array}$ & $\begin{array}{l}-0.469^{* * *} \\
(-4.027)\end{array}$ & $\begin{array}{l}2.622 \\
{[0.105]}\end{array}$ & $\begin{array}{l}14.131 \\
{[0.000]}\end{array}$ \\
\hline \multicolumn{7}{|c|}{ Panel C: The window length of the post period is 4 years } \\
\hline Baseline & $\begin{array}{l}0.219 \\
(1.233)\end{array}$ & $\begin{array}{l}0.020 \\
(0.111)\end{array}$ & $\begin{array}{l}-0.186 \\
(-1.616)\end{array}$ & $\begin{array}{l}-0.165 \\
(-1.628)\end{array}$ & $\begin{array}{l}5.376 \\
{[0.020]}\end{array}$ & $\begin{array}{l}5.330 \\
{[0.021]}\end{array}$ \\
\hline With $L M F$ & $\begin{array}{l}0.248 \\
(1.470)\end{array}$ & $\begin{array}{l}0.053 \\
(0.314)\end{array}$ & $\begin{array}{l}-0.449 \\
(-1.178)\end{array}$ & $\begin{array}{l}-0.377^{* *} \\
(-2.240)\end{array}$ & $\begin{array}{l}3.440 \\
{[0.064]}\end{array}$ & $\begin{array}{l}9.622 \\
{[0.002]}\end{array}$ \\
\hline With IC & $\begin{array}{l}0.353^{*} \\
(1.920)\end{array}$ & $\begin{array}{l}0.168 \\
(0.912)\end{array}$ & $\begin{array}{l}-0.192^{* *} \\
(-2.374)\end{array}$ & $\begin{array}{l}-0.254^{* * *} \\
(-4.725)\end{array}$ & $\begin{array}{l}7.144 \\
{[0.008]}\end{array}$ & $\begin{array}{l}9.858 \\
{[0.002]}\end{array}$ \\
\hline With FEL & $\begin{array}{l}0.177 \\
(1.063)\end{array}$ & $\begin{array}{l}-0.024 \\
(-0.144)\end{array}$ & $\begin{array}{l}-1.370 \\
(-2.163)\end{array}$ & $\begin{array}{l}-1.181^{* * *} \\
(-3.798)\end{array}$ & $\begin{array}{l}6.400 \\
{[0.011]}\end{array}$ & $\begin{array}{l}19.862 \\
{[0.000]}\end{array}$ \\
\hline With EW & $\begin{array}{l}0.159 \\
(0.938)\end{array}$ & $\begin{array}{l}-0.036 \\
(-0.210)\end{array}$ & $\begin{array}{l}-0.271^{*} \\
(-1.853)\end{array}$ & $\begin{array}{l}-0.448^{* * *} \\
(-3.726)\end{array}$ & $\begin{array}{l}5.256 \\
{[0.022]}\end{array}$ & $\begin{array}{l}12.633 \\
{[0.000]}\end{array}$ \\
\hline
\end{tabular}

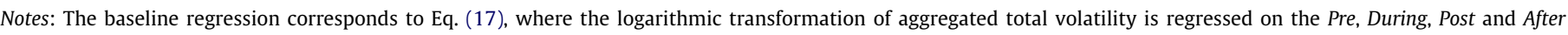

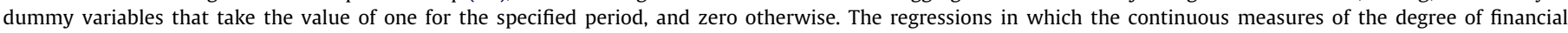

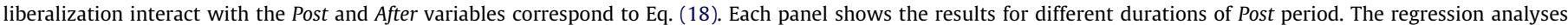

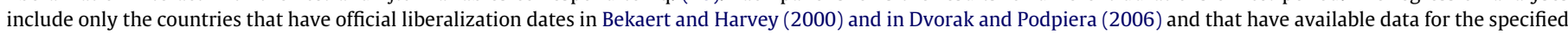

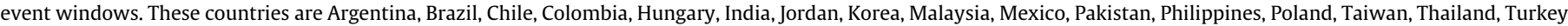

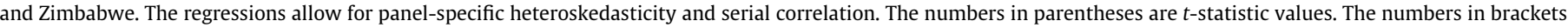
are the $p$-values of the Wald test for the difference of the coefficients.

Represents $10 \%$ significance level.

** Represents 5\% significance level.

*** Represents $1 \%$ significance level.

of financial liberalization after the initial relaxations of restrictions.

$$
\begin{aligned}
\log \hat{\sigma}_{\text {alt }}^{2}= & \alpha_{l}+\beta_{1} \text { Pre }_{l t}+\beta_{2} \text { During }_{l t}+\beta_{3} \text { Finlib }_{l t} \text { Post }_{l t} \\
& +\beta_{4} \text { Finlib }_{l t} \text { After }_{l t}+\varepsilon_{l t} .
\end{aligned}
$$

Here, Finlib represents one of the four aforementioned measures for the degree of financial liberalization. Note that the above specification is a similar version of the employed regression analyses in the previous section for the periods after the initial liberalization. The main difference in this specification is that the slope coefficients reflect the relative changes in volatility with respect to the period prior to Pre. Therefore, this specification enables us to compare the volatility in different periods.

We present the results of both regression specifications in Table 3. Each panel shows the results of the regression Eqs. (17) and (18), in which the duration of the Post period differs. Different window lengths for the Post period enable us to observe the evolution of changes in the level of volatility after liberalization. In each panel, baseline regressions indicate a decrease in aggregated total volatility from the Pre to Post periods. These results are in line with those obtained under the continuous modeling of financial liberalization in the previous sections. However, Panel $\mathrm{C}$ shows that the decrease is only significant at the five percent level (the $p$-value of the Wald test for the difference of the Pre and Post coefficients of the baseline model is 0.02), where the duration of the Post period is four years. These results point out that it takes time for the aggregated total volatility to reach a new level after the first liberalization of the markets. The results of the regression equation that distinguishes between partial and more complete liberalizations provide further insight about the relationship between aggregated total volatility and the degree of financial liberalization. When the volatility reaches its new level during the post-liberalization period, we observe that the difference between the coefficients of Pre and Post increases for nearly all specifications distinguishing between the partial and more complete liberalizations (the specifications with $L M F$, IC and FEL in Panel C of Table 4). The results of this section suggest that more complete liberalizations are associated with sharper declines in aggregated total volatility. In summary, the negative association between volatility and financial liberalization that is documented in the previous sections continues to hold for the binary modeling of financial liberalization and for an alternative time period. The decline of volatility to its new level may take up to four years after liberalization; this result is comparable to that of Kim and Singal's (2000), which points out a significant 
Table 4

Aggregated total volatility and the degree of financial liberalization: splitting the sample according to the size of the GDP.

\begin{tabular}{|c|c|c|c|c|}
\hline \multicolumn{5}{|c|}{ Panel A: Small-GDP subsample } \\
\hline$L M F$ & $\begin{array}{l}-0.647^{* *} \\
(2.135)\end{array}$ & & & \\
\hline IC & & $\begin{array}{l}-0.171^{* * *} \\
(3.451)\end{array}$ & & \\
\hline FEL & & & $\begin{array}{l}-1.119^{* * *} \\
(2.839)\end{array}$ & \\
\hline$E W$ & & & & $\begin{array}{l}-0.527^{* *} \\
(2.157)\end{array}$ \\
\hline TO & $\begin{array}{c}-0.034 \\
(0.500)\end{array}$ & $\begin{array}{c}-0.034 \\
(0.500)\end{array}$ & $\begin{array}{l}0.006 \\
(0.100)\end{array}$ & $\begin{array}{l}0.038 \\
(0.496)\end{array}$ \\
\hline Size & $\begin{array}{l}0.813^{* * *} \\
(3.447)\end{array}$ & $\begin{array}{l}0.839^{* * *} \\
(4.262)\end{array}$ & $\begin{array}{l}0.558^{* * *} \\
(2.877)\end{array}$ & $\begin{array}{l}-0.747^{* *} \\
(2.177)\end{array}$ \\
\hline Asian-RussianCrisis & $\begin{array}{l}0.413^{* * * *} \\
(3.392)\end{array}$ & $\begin{array}{l}0.369^{* * *} \\
(3.154)\end{array}$ & $\begin{array}{l}0.350^{* * *} \\
(2.891)\end{array}$ & $\begin{array}{l}0.532^{* * * *} \\
(4.714)\end{array}$ \\
\hline PesoCrisis & $\begin{array}{l}0.497^{* *} \\
(2.371)\end{array}$ & $\begin{array}{l}0.563^{* * *} \\
(2.688)\end{array}$ & $\begin{array}{l}0.472^{* *} \\
(2.183)\end{array}$ & $\begin{array}{l}0.735^{* * *} \\
(4.138)\end{array}$ \\
\hline Country fixed effects & Yes & Yes & Yes & Yes \\
\hline Ad. $R^{2}$ & 0.587 & 0.642 & 0.612 & 0.631 \\
\hline \multicolumn{5}{|c|}{ Panel B: Medium-GDP subsample } \\
\hline$L M F$ & $\begin{array}{r}-0.289 \\
(1.075)\end{array}$ & & & \\
\hline IC & & $\begin{array}{l}-0.194^{* * *} \\
(2.651)\end{array}$ & & \\
\hline FEL & & & $\begin{array}{r}-0.560 \\
(1.540)\end{array}$ & \\
\hline EW & & & & $\begin{array}{l}-0.932^{* *} \\
(2.274)\end{array}$ \\
\hline TO & $\begin{array}{l}0.970^{* * *} \\
(3.978)\end{array}$ & $\begin{array}{l}0.714^{* *} \\
(2.587)\end{array}$ & $\begin{array}{l}0.972^{* * *} \\
(4.248)\end{array}$ & $\begin{array}{l}0.980^{* * *} \\
(4.261)\end{array}$ \\
\hline Size & $\begin{array}{l}-0.368^{* *} \\
(2.110)\end{array}$ & $\begin{array}{l}-0.345^{*} \\
(1.970)\end{array}$ & $\begin{array}{l}-0.441^{* * *} \\
(2.734)\end{array}$ & $\begin{array}{l}-0.392^{* * *} \\
(2.631)\end{array}$ \\
\hline Asian-RussianCrisis & $\begin{array}{l}1.041^{* * * *} \\
(7.557)\end{array}$ & $\begin{array}{l}0.986 \\
(7.415)\end{array}$ & $\begin{array}{l}0.999^{* * * *} \\
(7.488)\end{array}$ & $\begin{array}{l}0.970 \\
(7.280)\end{array}$ \\
\hline PesoCrisis & $\begin{array}{l}0.016 \\
(0.048)\end{array}$ & $\begin{array}{l}0.009 \\
(0.028)\end{array}$ & $\begin{array}{l}0.025 \\
(0.076)\end{array}$ & $\begin{array}{l}0.028 \\
(0.084)\end{array}$ \\
\hline Country fixed effects & Yes & Yes & Yes & Yes \\
\hline Ad. $R^{2}$ & 0.492 & 0.524 & 0.494 & 0.502 \\
\hline \multicolumn{5}{|c|}{ Panel C: Large-GDP subsample } \\
\hline$L M F$ & $\begin{array}{l}0.261 \\
(0.531)\end{array}$ & & & \\
\hline IC & & $\begin{array}{r}-0.108 \\
(1.117)\end{array}$ & & \\
\hline FEL & & & $\begin{array}{l}-0.813^{*} \\
(1.924)\end{array}$ & \\
\hline EW & & & & $\begin{array}{l}0.769^{* * *} \\
(3.325)\end{array}$ \\
\hline TO & $\begin{array}{l}0.210^{* * *} \\
(2.762)\end{array}$ & $\begin{array}{l}-0.274^{* * *} \\
(3.127)\end{array}$ & $\begin{array}{l}0.233^{* * *} \\
(2.897)\end{array}$ & $\begin{array}{l}0.152^{* *} \\
(2.117)\end{array}$ \\
\hline Size & $\begin{array}{l}-1.493^{* * * *} \\
(3.381)\end{array}$ & $\begin{array}{l}-1.745^{* * *} \\
(4.638)\end{array}$ & $\begin{array}{l}-1.091^{* * * *} \\
(3.198)\end{array}$ & $\begin{array}{l}-1.778^{* * *} \\
(5.816)\end{array}$ \\
\hline Asian-RussianCrisis & $\begin{array}{l}0.643^{* * *} \\
(4.385)\end{array}$ & $\begin{array}{l}0.685^{* * *} \\
(4.396)\end{array}$ & $\begin{array}{l}0.575^{* * *} \\
(4.012)\end{array}$ & $\begin{array}{l}0.701^{* * *} \\
(5.153)\end{array}$ \\
\hline PesoCrisis & $\begin{array}{l}0.543^{*} \\
(1.868)\end{array}$ & $\begin{array}{l}0.474^{*} \\
(1.700)\end{array}$ & $\begin{array}{l}0.378 \\
(1.398)\end{array}$ & $\begin{array}{l}0.617 \\
(2.102)\end{array}$ \\
\hline Country fixed effects & Yes & Yes & Yes & Yes \\
\hline Ad. $R^{2}$ & 0.438 & 0.472 & 0.458 & 0.499 \\
\hline
\end{tabular}

Notes: The logarithm of aggregated total volatility is the dependent variable. The table presents the results for three different subsamples that are formed according to the ranking of the size of the GDP. Panel A indicates the results for the small-GDP subsample, which includes Chile, the Czech Republic, Hungary, Jordan, Morocco, Peru, Pakistan, Philippines and Zimbabwe. The medium-GDP subsample consists of Argentina, Colombia, Indonesia, Israel, Malaysia, Poland, South Africa and Thailand and Panel B of the table presents the regression results of this subsample. Panel C shows the regression results for the large-GDP subsample, which contains Brazil, China, India, Korea, Mexico, Russia, Taiwan, and Turkey. The regressions allow for panel-specific heteroskedasticity and serial correlation. The numbers in parentheses are $t$-statistic values.

* Represents 10\% significance level.

** Represents 5\% significance level.

**** Represents $1 \%$ significance level.

decrease in stock-return volatility in the fourth and fifth years after financial liberalization.

\subsection{Splitting the sample according to size of economy}

We further test the robustness of the previously reported results by investigating if they depend on the size of the economy. For this purpose, we rank the countries according to their GDPs. ${ }^{16}$ We analyze the relation between aggregated total volatility and the degree of financial liberalization for the three subsamples that differ in GDP size. We report the results for each subsample in the three panels of Table 4. In Panel A, we document sharp significant negative effects of all the degree of financial liberalization measures on aggregated total volatility for the small-GDP subsample. In Panel B, where the results for the medium-GDP subsample are presented, we again observe a negative association between all measures of financial liberalization and volatility. However, only IC and EW significantly impact total volatility, with the coefficients of -0.194 and -0.932 , respectively. Finally, for the large-GDP subsample of Panel C, the results show that a negative statistically significant relationship exists between aggregated total volatility and the degree of financial liberalization in only one specification where the degree of financial liberalization is represented by FEL (with a coefficient of -0.813 ). Conversely, EW has a positive statistically significant relationship with aggregated total volatility. In short, for the large-GDP subsample we do not observe a consistent significant relationship between aggregated total volatility and the degree of financial liberalization.

Consequently, these results suggest that volatility effect of the degree of financial liberalization is more pronounced for small and medium-sized economies. ${ }^{17}$ This finding may be interpreted as an implication of the investor-base broadening phenomena. As the investor-base broadens in the local markets with the increasing degree of financial liberalization, total stock-return volatility decreases. The marginal effects of investor-base broadening can be higher in the small markets with limited number of investors as compared to more developed markets where many local investors participate. This can partially explain why we observe a decrease in volatility especially for the relatively small markets.

\section{Further analyses of volatility components}

We further try to understand through which channels the degree of financial liberalization affects aggregated total volatility. We examine the three volatility components that are expressed in Eq. (9) in order to determine which components are responsible for the observed decrease in aggregated total volatility. For this purpose, we regress each of the three volatility components on the measures of the degree of financial liberalization. Idiosyncratic volatility is the strongest candidate for a channel of influence for two reasons. First, it is the most important component of aggregated total volatility, as shown in Section 3.2. Secondly, as a market becomes more open, aggregated idiosyncratic volatility may experience a change in its level due to a change in the information environment caused by the participation of foreign investors. ${ }^{18}$ If

\footnotetext{
16 The countries with the eight highest GDPs (Brazil, China, India, Korea, Mexico, Russia, Taiwan and Turkey) form the large-GDP subsample. The next eight highest GDP countries (Argentina, Colombia, Indonesia, Israel, Malaysia, Poland, South Africa and Thailand) form the medium-GDP subsample. The small-GDP subsample consists of the remaining nine countries - those with the lowest GDPs (Chile, the Czech Republic, Hungary, Jordan, Morocco, Peru, Pakistan, Philippines and Zimbabwe).

17 We also split the sample according to the size of the stock exchanges and form subsamples depending on the size of market capitalizations. The results for the subsamples, which are not reported here, again reveal that the volatility effects are stronger for the small and medium-sized subsamples.

${ }^{18}$ Recent literature documents a relationship between institutional ownership and aggregated idiosyncratic volatility in developed markets (Xu and Malkiel, 2003). A similar relationship between foreign ownership and aggregated idiosyncratic volatility may hold in emerging markets. Foreign investors may heavily trade in the stocks that they have special information on, as institutional investors do in developed markets.
} 
foreign investors bring more firm-specific information into a local market with an increasing degree of financial liberalization, aggregated idiosyncratic volatility may increase. Conversely, new market participants may reveal local or global market-wide information rather than firm-specific information or may increase the precision of the public information. In such cases, a negative influence of liberalization process on idiosyncratic volatility is likely to occur. To investigate the possible relationship between the degree of financial liberalization and aggregated idiosyncratic volatility, we regress the logarithmic transformation of aggregated idiosyncratic volatility on the degree of financial liberalization which is represented by different measures and on the previously defined control variables and report the results in Panel A of Table 5. We observe that aggregated idiosyncratic volatility is negatively related to the degree of financial liberalization. Moreover, this relation persists under the alternative measures of the degree of financial liberalization. The regression results also show that liquidity has a positive significant impact on aggregated idiosyncratic volatility, whereas the market development stage has negative but mostly insignificant impacts. We also find that during Asian crisis, the aggregated idiosyncratic volatility increases. Interestingly, we find no significant change in the aggregated idiosyncratic volatility during the Peso crisis for most of the specifications. $^{19}$

Local volatility is another candidate for a channel of influence. In a previous section, we show that local volatility is the secondlargest component of total volatility after idiosyncratic volatility (see Table 1). Furthermore, we expect a drop in exposure to local factors as the local market integrates with the global market. Thus, local volatility is a potential channel through which the negative effect of the degree of financial liberalization can arise. We examine the relationship between the logarithmic transformation of local volatility and the degree of financial liberalization in several specifications and present the results in Panel B of Table 5. We detect a strong negative impact on local volatility for all measures of the degree of financial liberalization. The signs of the control variables remain in the expected direction, with significant effects.

Finally, we check whether global volatility contributes to the observed relationship between aggregated total volatility and the degree of financial liberalization. We regress log Global only on the degree of financial liberalization measures and the previously defined dummy variables and omit the other control variables because they are local market variables and not relevant to global volatility. ${ }^{20}$ The results in Panel C of Table 5 show that all the measures of the degree of financial liberalization are positively associated with global volatility and that $L M F, F E L$ and $E W$ have statistically significant impacts. We interpret the positive relationship between the degree of financial liberalization measures and global volatility as the result of the increased role of global factors due to the increased integration of local markets during the liberalization process. We conclude that while the degree of financial liberalization affects idiosyncratic and local volatilities negatively, it affects global volatility positively. The combined effect of the degree of financial liberalization through volatility components is a net decrease in aggregated total volatility.

\subsection{Robustness checks}

\subsubsection{Alternative order of orthogonalization}

We derive the volatility components from the modified market model, which uses orthogonalized returns with respect to the glo-

\footnotetext{
19 The view that the factors that arise during the Peso crisis are more related to the systematic risk than to the idiosyncratic risk of stocks can partly explain this finding. The positive significant coefficients of Peso crisis dummies, shown in Panel B of Table 5 , support this view.

${ }^{20}$ Some other global factors, such as changes in oil prices, may induce global volatility, but the determinants of global volatility are beyond the scope of this study.
}

Table 5

Volatility components and the degree of financial liberalization.

\begin{tabular}{|c|c|c|c|c|}
\hline \multicolumn{5}{|c|}{ Panel A: Dependent variable is log Idiosyncratic } \\
\hline$L M F$ & $\begin{array}{l}-0.340 \\
(2.047)\end{array}$ & & & \\
\hline IC & & $\begin{array}{l}-0.137^{* * *} \\
(4.389)\end{array}$ & & \\
\hline FEL & & & $\begin{array}{l}-0.944^{* * *} \\
(4.653)\end{array}$ & \\
\hline EW & & & & $\begin{array}{l}-0.435^{* * *} \\
(-2.905)\end{array}$ \\
\hline TO & $\begin{array}{l}0.117^{* *} \\
(2.483)\end{array}$ & $\begin{array}{l}0.091^{*} \\
(1.854)\end{array}$ & $\begin{array}{l}0.134^{* * *} \\
(3.063)\end{array}$ & $\begin{array}{l}0.204^{* * *} \\
(3.791)\end{array}$ \\
\hline Size & $\begin{array}{l}-0.057 \\
(0.471)\end{array}$ & $\begin{array}{r}-0.033 \\
(0.291)\end{array}$ & $\begin{array}{c}-0.134 \\
(1.282)\end{array}$ & $\begin{array}{l}-0.367^{* * *} \\
(3.175)\end{array}$ \\
\hline Asian-RussianCrisis & $\begin{array}{l}0.535^{* *} \\
(7.492)\end{array}$ & $\begin{array}{l}0.558^{* * *} \\
(7.846)\end{array}$ & $\begin{array}{l}0.497^{* * *} \\
(7.109)\end{array}$ & $\begin{array}{l}0.526^{* * *} \\
(7.982)\end{array}$ \\
\hline PesoCrisis & $\begin{array}{l}0.186 \\
(1.264)\end{array}$ & $\begin{array}{l}0.211 \\
(1.525)\end{array}$ & $\begin{array}{l}0.144 \\
(0.981)\end{array}$ & $\begin{array}{l}0.225^{*} \\
(1.657)\end{array}$ \\
\hline Country fixed effects & Yes & Yes & Yes & Yes \\
\hline Ad. $R^{2}$ & 0.477 & 0.542 & 0.498 & 0.576 \\
\hline
\end{tabular}

Panel B: Dependent variable is $\log$ Local

LMF $-0.512^{* * *}$

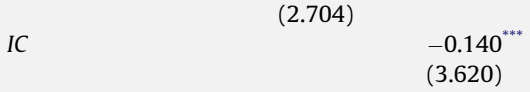

FEL

EW

TO

Size

Asian-RussianCrisis

PesoCrisis

Country fixed effects

Ad. $R^{2}$

-1.380
$(5.511)$

$-0.400 *$

(2.211)

$0.204^{* * *}$

(3.263)

$\begin{array}{llll}(2.778) & (2.173) & (3.684) & (3.263) \\ -0.541^{* * *} & -0.478^{* * *} & -0.636^{* * *} & -0.980^{* * *} \\ (3.123) & (2.836) & (4.241) & (6.082)\end{array}$

$\begin{array}{llll}(2.778) & (2.173) & (3.684) & (3.263) \\ -0.541^{* * *} & -0.478^{* * *} & -0.636^{* * *} & -0.980^{* * *} \\ (3.123) & (2.836) & (4.241) & (6.082) \\ 0.578^{* * *} & 0.512^{* * *} & 0.547^{* * *} & 0.591^{* * *}\end{array}$

$\begin{array}{llll}(6.733) & (5.859) & (6.485)\end{array}$

$\begin{array}{llll}0.774^{* * *} & 0.814^{* * *} & 0.775^{* * *} & 0.894^{* * *} \\ (4.567) & (4.728) & (4.957) & (5.842)\end{array}$

$\begin{array}{llll}\text { Yes } & \text { Yes } & \text { Yes } & \text { Yes }\end{array}$

Panel C: Dependent variable is log Global

LMF $2.326^{* * *}$

IC

(5.253)

FEL

0.047

FEL

(0.612)

EW

$\begin{array}{ll}\text { Asian-RussianCrisis } & 1.174^{* * *} \\ & (5.299) \\ \text { PesoCrisis } & 0.573 \\ & (1.510) \\ \text { Country fixed effects } & \text { Yes } \\ \text { Ad. } R^{2} & 0.439\end{array}$

Notes: The table reports the results of the regression of the volatility components on the alternative measures of the degree of financial liberalization and on the control variables. Panel A, Panel B and Panel C indicate the results of the panel regressions where the dependent variable is the logarithmic transformation of Idiosyncratic Local and Global, respectively. The regressions allow for panel-specific heteroskedasticity and serial correlation. The numbers in parentheses are $t$-statistic values. * Represents $10 \%$ significance level.

** Represents 5\% significance level.

*** Represents $1 \%$ significance level.

bal market portfolio return. Clayton and Mackinnon (2003) point out an overpurging problem in such an orthogonalization process. In our case, this problem means that if stock-return volatility is driven to some extent by factors that are common to local and global effects, then the effects of these common factors are attributable only to global factors, and the effects of the local factors are overpurged. In order to handle this potential problem, we change the order of the orthogonalization process and take the local index return as the base. We obtain new versions of volatility components 
Table 6

Volatility components and the degree of financial liberalization under the alternative order of orthogonalization.

\begin{tabular}{|c|c|c|c|c|}
\hline \multicolumn{5}{|c|}{ Panel A: Dependent variable is log Idiosyncratic } \\
\hline$L M F$ & $\begin{array}{l}-0.304^{*} \\
(1.820)\end{array}$ & & & \\
\hline IC & & $\begin{array}{l}-0.135^{* * *} \\
(4.288)\end{array}$ & & \\
\hline$F E L$ & & & $\begin{array}{l}-0.925^{* * *} \\
(4.572)\end{array}$ & \\
\hline EW & & & & $\begin{array}{l}-0.413^{* * *} \\
(2.768)\end{array}$ \\
\hline TO & $\begin{array}{l}0.117^{* *} \\
(2.487)\end{array}$ & $\begin{array}{l}0.092^{*} \\
(1.863)\end{array}$ & $\begin{array}{l}0.134^{* * *} \\
(3.039)\end{array}$ & $\begin{array}{l}0.204^{* * *} \\
(3.770)\end{array}$ \\
\hline Size & $\begin{array}{l}-0.081 \\
(0.670)\end{array}$ & $\begin{array}{l}-0.052 \\
(0.460)\end{array}$ & $\begin{array}{r}-0.145 \\
(1.394)\end{array}$ & $\begin{array}{l}-0.383^{* * *} \\
(3.312)\end{array}$ \\
\hline Asian-RussianCrisis & $\begin{array}{l}0.529^{* * *} \\
(7.430)\end{array}$ & $\begin{array}{l}0.553^{* * *} \\
(7.790)\end{array}$ & $\begin{array}{l}0.493^{* * *} \\
(7.070)\end{array}$ & $\begin{array}{l}0.522^{* * *} \\
(7.944)\end{array}$ \\
\hline PesoCrisis & $\begin{array}{l}0.176 \\
(1.201)\end{array}$ & $\begin{array}{l}0.195 \\
(1.407)\end{array}$ & $\begin{array}{l}0.131 \\
(0.898)\end{array}$ & $\begin{array}{l}0.213 \\
(1.575)\end{array}$ \\
\hline Country fixed effects & Yes & Yes & Yes & Yes \\
\hline Ad. $R^{2}$ & 0.474 & 0.539 & 0.497 & 0.576 \\
\hline \multicolumn{5}{|c|}{ Panel B: Dependent variable is $\log$ Local } \\
\hline$L M F$ & $\begin{array}{l}-0.128 \\
(0.666)\end{array}$ & & & \\
\hline IC & & $\begin{array}{l}-0.115^{* * *} \\
(3.099)\end{array}$ & & \\
\hline FEL & & & $\begin{array}{l}-0.863^{* * *} \\
(3.473)\end{array}$ & \\
\hline EW & & & & $\begin{array}{l}-0.076 \\
(0.422)\end{array}$ \\
\hline TO & $\begin{array}{l}0.163^{* * *} \\
(3.010)\end{array}$ & $\begin{array}{l}0.157^{* * *} \\
(2.711)\end{array}$ & $\begin{array}{l}0.188^{* * *} \\
(3.566)\end{array}$ & $\begin{array}{l}0.206^{* * *} \\
(3.368)\end{array}$ \\
\hline Size & $\begin{array}{l}-0.499^{* * * *} \\
(2.859)\end{array}$ & $\begin{array}{l}-0.339^{* *} \\
(2.035)\end{array}$ & $\begin{array}{l}-0.488^{* * *} \\
(3.208)\end{array}$ & $\begin{array}{l}-0.867^{* * *} \\
(5.183)\end{array}$ \\
\hline Asian-RussianCrisis & $\begin{array}{l}0.652^{* * *} \\
(7.589)\end{array}$ & $\begin{array}{l}0.619^{* * *} \\
(7.192)\end{array}$ & $\begin{array}{l}0.639^{* * * *} \\
(7.517)\end{array}$ & $\begin{array}{l}0.651^{* *} \\
(7.757)\end{array}$ \\
\hline PesoCrisis & $\begin{array}{l}0.714^{* * *} \\
(4.406)\end{array}$ & $\begin{array}{l}0.674^{* * *} \\
(4.152)\end{array}$ & $\begin{array}{l}0.667^{* * * *} \\
(4.393)\end{array}$ & $\begin{array}{l}0.763^{* * *} \\
(5.006)\end{array}$ \\
\hline Country fixed effects & Yes & Yes & Yes & Yes \\
\hline Ad. $R^{2}$ & 0.538 & 0.557 & 0.557 & 0.592 \\
\hline \multicolumn{5}{|c|}{ Panel C: Dependent variable is log Global } \\
\hline$L M F$ & $\begin{array}{l}4.211^{* * *} \\
(8.037)\end{array}$ & & & \\
\hline IC & & $\begin{array}{l}0.186^{*} \\
(1.814)\end{array}$ & & \\
\hline FEL & & & $\begin{array}{l}6.179^{* * *} \\
(9.042)\end{array}$ & \\
\hline EW & & & & $\begin{array}{l}4.317^{* * *} \\
(8.756)\end{array}$ \\
\hline Asian-RussianCrisis & $\begin{array}{l}0.868^{* * *} \\
(3.259)\end{array}$ & $\begin{array}{l}0.541^{* *} \\
(2.150)\end{array}$ & $\begin{array}{l}0.852^{* * *} \\
(3.233)\end{array}$ & $\begin{array}{l}0.601^{* *} \\
(2.372)\end{array}$ \\
\hline PesoCrisis & $\begin{array}{l}-1.667^{* * * *} \\
(3.590)\end{array}$ & $\begin{array}{l}-0.520^{* * * *} \\
(5.042)\end{array}$ & $\begin{array}{l}-2.055^{* * *} \\
(4.445)\end{array}$ & $\begin{array}{l}-2.310^{* * *} \\
(4.729)\end{array}$ \\
\hline Country fixed effects & Yes & Yes & Yes & Yes \\
\hline Ad. $R^{2}$ & 0.367 & 0.355 & 0.393 & 0.414 \\
\hline
\end{tabular}

Notes: The table reports the results of the regression of the volatility components, which are constructed under the alternative order of orthogonalization, on the alternative measures of the degree of financial liberalization and on the contro variables. Panel A, Panel B and Panel $C$ report the results of the panel regressions where the dependent variable is the logarithmic transformation of Idiosyncratic, Local and Global, respectively. The regressions allow for panel-specific heteroskedasticity and serial correlation. The numbers in parentheses are $t$-statistic values.

* Represents $10 \%$ significance level.

* Represents 5\% significance level.

Represents $1 \%$ significance level.

with this order of orthogonalization, giving more emphasis to local factors and use this set of volatility components as dependent variables in the regression analyses. ${ }^{21}$ Thus, we can assess whether our results are affected by the potential overpurging problem.

\footnotetext{
21 The derivation details of the new set of volatility components are available upon request.
}

Table 7

Alternative definition of aggregated idiosyncratic volatility and the degree of financial liberalization.

\begin{tabular}{|c|c|c|c|c|}
\hline$L M F$ & $\begin{array}{l}-0.442^{* *} \\
(2.534)\end{array}$ & & & \\
\hline IC & & $\begin{array}{l}-0.145^{* * *} \\
(4.443)\end{array}$ & & \\
\hline FEL & & & $\begin{array}{l}-0.952^{* * *} \\
(4.373)\end{array}$ & \\
\hline EW & & & & $\begin{array}{l}-0.061 \\
(0.390)\end{array}$ \\
\hline TO & $\begin{array}{l}0.132^{* * *} \\
(2.875)\end{array}$ & $\begin{array}{l}0.142^{* * *} \\
(2.867)\end{array}$ & $\begin{array}{l}0.166^{* * *} \\
(3.790)\end{array}$ & $\begin{array}{l}0.199^{* * *} \\
(4.064)\end{array}$ \\
\hline Size & $\begin{array}{l}-0.256^{*} \\
(1.923)\end{array}$ & $\begin{array}{l}-0.318^{* * *} \\
(2.677)\end{array}$ & $\begin{array}{l}-0.359^{* * *} \\
(3.235)\end{array}$ & $\begin{array}{l}-0.676^{* * *} \\
(4.994)\end{array}$ \\
\hline Asian-RussianCrisis & $\begin{array}{l}0.560^{* * *} \\
(7.495)\end{array}$ & $\begin{array}{l}0.590^{* * *} \\
(7.751)\end{array}$ & $\begin{array}{l}0.072^{* * *} \\
(7.031)\end{array}$ & $\begin{array}{l}0.543^{* * *} \\
(7.958)\end{array}$ \\
\hline PesoCrisis & $\begin{array}{l}0.281^{*} \\
(1.966)\end{array}$ & $\begin{array}{l}0.311^{* *} \\
(2.248)\end{array}$ & $\begin{array}{l}0.233 \\
(1.600)\end{array}$ & $\begin{array}{l}0.342^{* *} \\
(2.343)\end{array}$ \\
\hline Country fixed effects & Yes & Yes & Yes & Yes \\
\hline Ad. $R^{2}$ & 0.473 & 0.534 & 0.483 & 0.554 \\
\hline
\end{tabular}

Notes: Model-independent measure of aggregated idiosyncratic volatility proposed by Bali et al. (2008) is the dependent variable in the panel regressions. The regressions allow for panel-specific heteroskedasticity and serial correlation. The numbers in parentheses are $t$-statistic values.

* Represents 10\% significance level.

** Represents 5\% significance level.

Represents $1 \%$ significance level.

Table 6 provides the results of the regression of the dependent variables, which are constructed under the alternative order of orthogonalization on the alternative measures of the degree of financial liberalization and on the control variables. Again, in each panel we provide the results for the regressions that have different dependent variables. Under this order of orthogonalization, the alternative measures of the degree of financial liberalization preserve their negative impact on $\log$ Idiosyncratic and $\log$ Local for all specifications, though this impact loses its significance for a few specifications. On the other hand, we detect a significant positive relationship between log Global and the degree of financial liberalization again for all specifications. Thus, we obtain similar findings under the alternative order of orthogonalization, suggesting that the potential overpurging problem does not seriously affect our results.

\subsubsection{Model-independent definition of aggregated idiosyncratic volatility}

We derive our aggregated idiosyncratic volatility measure from the modified market model, and therefore one can argue that the conclusions drawn are model dependent. In order to asses the robustness of the results for aggregated idiosyncratic volatility in Tables 5 and 6, we use the model-independent measure of aggregate idiosyncratic volatility proposed by Bali et al. (2008). In their study, they define a non-diversified portfolio in which the correlations among the stock returns equal one. Such a portfolio contains both the systematic risk and idiosyncratic risk of individual stocks. They also consider a fully diversified portfolio such as the stock market index. Because the idiosyncratic risk is eliminated in a fully diversified portfolio, the total risk of this portfolio is due to the systematic risk of the stocks in the portfolio. They define the new measure of average idiosyncratic volatility as the difference between the return variance of the non-diversified portfolio and the return variance of the fully diversified portfolio. ${ }^{22}$ We use this new measure to determine whether our results are sensitive to the definition of idiosyncratic volatility. We construct a portfolio

\footnotetext{
${ }^{22}$ See the technical details in Bali et al. (2008) for constructing the model-
} independent idiosyncratic volatility. 
composed of the stocks in the IFC global index of the emerging markets as the non-diversified portfolio, assuming that the correlation between stock returns is equal to one. We use the EMDB local index of the relevant country as the fully diversified portfolio. We repeat our tests with the alternative definition of idiosyncratic volatility, and document the results in Table 7. We still observe a negative significant effect of the degree of financial liberalization on log Idiosyncratic for almost all specifications. Thus, we replicate our previous finding of a negative significant relationship between idiosyncratic volatility and the degree of financial liberalization with a modelindependent measure of idiosyncratic volatility.

\section{Conclusion}

In this study, we address the question of whether the degree of financial liberalization affects the aggregated total volatility of stock returns by accounting for the time-varying nature of financial liberalization. Unlike previous studies, we examine the aggregated return volatility of individual stocks rather than the return volatility of the market portfolio. The aggregated return volatility used in this study is a pure measure of the average return volatility of stocks in a country and thus the correlations between the stock returns in a portfolio do not affect our results. We further investigate through which channels the degree of financial liberalization affects aggregated total volatility.

The results show that aggregated total volatility is negatively related to the degree of financial liberalization, even after controlling for market development, liquidity, country and crisis effects, especially for small and medium-sized emerging markets. Hence, the increasing degree of financial liberalization has a decreasing impact on aggregated total volatility. The analysis of the components of aggregated total volatility also reveals that the degree of financial liberalization transmits its negative impact on aggregated total volatility through aggregated idiosyncratic and local volatilities. On the other hand, we document a positive relationship between the degree of financial liberalization and global volatility. We obtain similar results with the alternative order of orthogonalization in the volatility decomposition process and with the alternative model-independent definition of idiosyncratic volatility. Our results are consistent with the view that the broadened investor base with foreign investors brought about by financial liberalization improves the accuracy of public information and thus reduces volatility. The findings of this study provide implications for governments' policies regarding financial liberalization, which affects firms' abilities to raise capital in order to undertake profitable projects, and to contribute to overall economic growth.

In this study we deal with the volatility effects of the degree of financial liberalization, which is proxied by different openness measures to cross-border transactions. Trading activity of foreign investors measured either in the form of equity flows or of trading volume may be a more direct measure of foreign investor participation. Moreover, emerging markets are the markets that attract the attention of home-based individual investors, who are blamed for increasing volatility. Therefore, investigating the volatility effects of trading activity by foreign and individual domestic investors may provide additional insights. We leave these issues for a further study when reliable foreign and domestic trading activity data become available for more emerging markets.

\section{Acknowledgements}

We thank Suk-Joong Kim, Lieven Baele, seminar and conference participants at Bilkent University, Çankaya University, Tilburg University, 2008 INFINITI Conference on International Finance and especially Frank de Jong, Refet Gurkaynak and an anonymous referee for helpful comments and suggestions on an earlier version of this paper. Gian Maria Milesi-Ferretti generously provided an up-to-date version of External Wealth of Nations Mark II data set. Some parts of this paper were written when Umutlu was visiting Tilburg University. The authors acknowledge the financial support from The Scientific and Technological Research Council of Turkey (Contract No. 106K203).

\section{References}

Bae, K., Chan, K., Ng, A., 2004. Investibility and return volatility. Journal of Financial Economics 71, 239-263.

Bali, T.G., Cakici, N., Levy, H., 2008. A model-independent measure of aggregate idiosyncratic risk. Journal of Empirical Finance 15, 878-896.

Bekaert, G., Harvey, C., 1995. Time-varying world market integration. Journal of Finance 50, 403-444.

Bekaert, G., Harvey, C., 2000. Foreign speculators in emerging equity markets. Journal of Finance 55, 565-613.

Bekaert, G., Harvey, C., 2002. Research in emerging markets finance: Looking to the future. Emerging Markets Review 3, 429-448.

Bekaert, G., Harvey, C., Lundblad, C., 2005. Does financial liberalization spur growth? Journal of Financial Economics 77, 3-55

Chari, A., Henry, P.Y., 2004. Risk sharing and asset prices: Evidence from a natural experiment. Journal of Finance 59, 1295-1324.

Chin, M.D., Ito, H., 2007. A new measure of financial openness. Journal of Comparative Policy Analysis: Research and Practice 10, 309-322.

Campbell, J.Y., Lettau, M., Malkiel, B.G., Xu, Y., 2001. Have individual stocks become more volatile? An empirical exploration of idiosyncratic risk. Journal of Finance $56,1-43$.

Clayton, J., Mackinnon, G., 2003. The relative importance of stock, bond and real estate factors in explaining REIT returns. Journal of Real Estate Finance and Economics 27, 39-60.

De La Torre, A., Gozzi, J.C., Schmukler, S.L., 2007. Stock market development under globalization: Whither the gains from reforms? Journal of Banking and Finance 31, 1731-1754

De Jong, F., De Roon, F.A., 2005. Time-varying market integration and expected returns in emerging markets. Journal of Financial Economics 78 583-613.

De Santis, G., Imrohoroglu, S., 1997. Stock returns and volatility in emerging financial markets. Journal of International Money and Finance 16, 561579.

Domowitz, I., Glen, J., Madhavan, A., 1998. International cross-listing and order flow migration: Evidence from an emerging market. Journal of Finance 53, 20012027.

Dvorak, T., Podpiera, R., 2006. European Union enlargement and equity markets in accession countries. Emerging Markets Review 7, 129-146.

Edison, H.J., Warnock, F.E., 2003. A simple measure of the intensity of capital controls. Journal of Empirical Finance 10, 81-103.

Errunza, V., Losq, E., 1985. International asset pricing under mild segmentation: Theory and test. The Journal of Finance 40, 105-124.

Fama, E.F., MacBeth, J.D., 1973. Risk, return and equilibrium: Empirical tests. Journal of Political Economy 81, 607-636.

Fernandes, N., Ferreira, M., 2008. Does international cross-listing improve the information environment? Journal of Financial Economics 88, 216-244.

Ferreira, M.A., Gama, P.M., 2005. Have world, country, and industry risks changed over time? An investigation of the volatility of developed stock markets. Journal of Financial and Quantitative Analysis 40, 195-222.

Foerster, S.R., Karolyi, G.A., 1999. The effects of market segmentation and investor recognition on asset prices: Evidence from foreign stocks listings in the United States. Journal of Finance 54, 981-1013.

Hargis, K., 2002. Forms of foreign investment liberalization and risk in emerging markets. Journal of Financial Research 25, 19-38.

Harvey, C., 1995. Predictable risk and returns in emerging markets. Review of Financial Studies 8, 773-816.

Henry, P.B., 2000. Do stock market liberalizations cause investment booms? Journal of Financial Economics 58, 301-334.

Kim, H., Singal, V., 2000. Stock market openings: Experience of emerging economies Journal of Business 73, 25-66.

Kwan, F.B., Reyes, M.G., 1997. Price effects of stock market liberalization in Taiwan. The Quarterly Review of Economics and Finance 37, 511-522.

Lane, P.R., Milesi-Ferretti, G.M., 2007. The external wealth of nations mark II: Revised and extended estimates of foreign assets and liabilities, 1970-2004. Journal of International Economics 73, 223-250.

Lang, M.H., Lundholm, R.J., 1996. Corporate disclosure policy and analyst behavior The Accounting Review 71, 467-492.

Li, K., Morck, R., Yang, F., Yeung, B., 2004. Firm-specific variation and openness in emerging markets. Review of Economics and Statistics 86, 658-669.

Merton, R.C., 1987. A simple model of capital market equilibrium with incomplete information. The Journal of Finance 42, 483-510.

Moshirian, F., 2007. Globalisation and the role of effective international institutions. Journal of Banking and Finance 31, 1579-1593. 
Moshirian, F., 2008. Globalisation, growth and institutions. Journal of Banking and Finance 32, 472-479.

Panchenko, V., Wu, E., 2009. Time-varying market integration and stock and bond return concordance in emerging markets. Journal of Banking and Finance 33, 1014-1021.

Stiglitz, J.E., 2004. Capital-market liberalization, globalization, and the IMF. Oxford Review of Economic Policy 20, 57-71.
Umutlu, M., Altay-Salih, A., Akdeniz, L., 2007. Does ADR listing affect the dynamics of volatility in emerging markets? Working paper, Bilkent University.

Wang, J., 2007. Foreign equity trading and emerging market volatility: Evidence from Indonesia and Thailand. Journal of Development Economics 84, 798-811.

Xu, Y., Malkiel, B.G., 2003. Investigating the behavior of idiosyncratic volatility. Journal of Business 76, 613-664. 